Research Article

\title{
Performance of Yeast Microbial Fuel Cell Integrated with Sugarcane Bagasse Fermentation for COD Reduction and Electricity Generation
}

\author{
Marcelinus Christwardana*, J. Joelianingsih*, Linda Aliffia Yoshi \\ Department of Chemical Engineering, Institut Teknologi Indonesia, Jl. Raya Puspiptek Serpong, \\ South Tangerang, 15320, Indonesia.
}

Received: 12 ${ }^{\text {th }}$ December 2020; Revised: $12^{\text {th }}$ March 2021; Accepted: $12^{\text {th }}$ March 2021

Available online: $16^{\text {th }}$ March 2021; Published regularly: September 2021

\section{Abstract}

The purpose of this analysis is to evaluate the efficiency of the Microbial Fuel Cell (MFC) system incorporated with the fermentation process, with the aim of reducing COD and generating electricity, using sugarcane bagasse extract as a substrate, in the presence and absence of sugarcane fibers. There is a possibility of turning bagasse extract into renewable bioenergy to promote the sustainability of the environment and energy. As a result, the integration of liquid fermentation (LF) with MFC has improved efficiency compared to semi-solid state fermentation (S-SSF). The maximum power generated was $14.88 \mathrm{~mW} / \mathrm{m}^{2}$, with an average COD removal of $39.68 \%$ per cycle. The variation margin of the liquid fermentation $\mathrm{pH}$ readings remained slightly decrease, with a slight deflection of +0.14 occurring from 4.33 . With the absence of bagasse fibers, biofilm can grow freely on the anode surface so that the transfer of electrons is fast and produces a relatively high current. Experimental data showed a positive potential after an effective integration of the LF and MFC systems in the handling of waste. The product is then simultaneously converted into electrical energy.

Copyright (C) 2021 by Authors, Published by BCREC Group. This is an open access article under the CC BY-SA License (https://creativecommons.org/licenses/by-sa/4.0).

Keywords: sugarcane utilization; semi-aerobic fermentation; microbial fuel cell system; Relative Decrease in Cell Potential; COD removal

How to Cite: M. Christwardana, J. Joelianingsih, L.A. Yoshi (2021). Performance of Yeast Microbial Fuel Cell Integrated with Sugarcane Bagasse Fermentation for COD Reduction and Electricity Generation. Bulletin of Chemical Reaction Engineering \& Catalysis, 16(3), 446-458 (doi:10.9767/bcrec.16.3.9739.446-458)

Permalink/DOI: https://doi.org/10.9767/bcrec.16.3.9739.446-458

\section{Introduction}

Microbial fuel cells (MFCs) technology has recently experienced tremendous success in the conversion of waste to energy [1-3]. The process involves applying the concept of waste-to-energy (WtE), using microorganisms to catalyze direct electricity generation from organic materials, including glucose, ethanol, acetate, lactate, bu-

\footnotetext{
* Corresponding Author

Email: marcelinus@iti.ac.id (M. Christwardana); joelianingsih@iti.ac.id (J. Joelianingsih);

Telp: +62-21-7561092
}

tyrate, albumin, cysteine, amino acids, cellulose, marine sediments, and lignocellulosic substrates [4-9]. Also, various domestic and industrial wastes have been adopted in the process [10-13], and the redox technology widely applied between substrates and microorganisms in the production of renewable energy from biomass [14,15]. Moreover, some of the microbes used include pure anaerobic bacteria, facultative anaerobes, and mixed cultures [16-18].

The production of power, using the MFC system, is influenced by the configuration, type, and surface area of membranes, and electrodes, 
as well as the type of substrate, fuel concentration, genus, and electrophilic nature of microorganisms [19-21]. However, there have been major challenges while using solid biomass as a direct substrate, which consists of polysaccharides, including lignocellulose, starch, chitin, and chitosan. These are some of the terrestrial biopolymers known to be abundant in nature $[22,23]$.

Lignocellulose is a biopolymer with high energy content, although the property of insolubility proves to be problematic [24]. This compound comprises of cellulose, lignin, and hemicellulose, collectively regarded as the main elements required in the formation of all plant material, including tissues [25]. The abundance in nature and the possible application as a fuel reduces the running costs of MFC. Furthermore, it is possible to obtain lignocellulose waste from a variety of sources, including agricultural, domestic (vegetable and fruit), and industries (food industries linked with wood, vegetables, and fruit) [26]. Moreover, cellulose as a major natural component, comprises about $40 \%$ to $50 \%$ of the total dry weight [27]. This is known to possess a small amount of amorphous, and numerous crystalline portions, which is more resistant to chemical and enzymatic hydrolysis, and consequently affiliated with the insolubility [28]. The stubborn nature of lignocellulose poses a challenge during use as a direct substrate in MFCs. According to Mosier et al., pre-treatment is needed to break the structural complexity and further facilitates the ease of conversion into electricity by microorganisms [29]. The cellulose part is specifically broken down into simpler parts, including glucose, through hydrolysis, physical, or chemical processes [30]. Due to their maximum rate, ease of operation, simple operating conduction, and environmentally friendly properties, microbial hydrolysis is assumed to be more beneficial [31].

One of the most significant agro-industrial by-products with large lignocellulose component is a residue from sugarcane stalks after juice extraction, which is commonly known as sugarcane bagasse [32]. In recent years, attempts have been made to boost the utilization as fuel for the boilers in industries. However, possible applications for other purposes recorded encompass the production of electricity, biofuel, pulp, and paper, as well as fermentationbased products, including alcohol, alkaloids, fungi, animal feed enriched with single-cell protein, and enzymes [33-36]. Despite these benefits, the commercialization of bagasse-based processes remains limited, hence this research aims at investigating the limitations to the scope and the application of bagasse for the bioelectric conversion process.

Since sugarcane bagasse still contains $62.21 \%$ sugar as cellulose and hemicellulose [37], this may be a possible substrate where microorganisms can be used as biocatalysts for MFCs by utilizing sugar. Yeast from Saccharomyces cerevisiae is considered to act as a biocatalyst in MFC because it has several advantages over mixed culture in activated sludge, although mixed culture is reported to produce better electrical energy. The advantages of yeast include, has facilitated extracellular electron transfer, robust, fast-growing, facultative anaerobe, non-pathogenic, temperature tolerant microorganism, and easy to get [38-41]. Based on that, yeast is worth considering as a promising biocatalyst in treating sugarcane bagasse and converting it into electrical energy.

This research describes the utilization of sugar contained in extract of sugarcane bagasse waste as a substrate in the singlechambered yeast MFC, through a liquid fermentation (LF). The presence of sugarcane fibers in the incubation system was also evaluated through semi-solid state fermentation (S$\mathrm{SSF})$. This S-SSF selection was due to the compact and robust lignocellulosic structure, therefore augmenting the difficulty to create a welldistributed substrate with low water content. In addition, slurries with higher water content were used in this experiment, while the voltage and current density were measured over a certain period. Also, polarization and Relative Decrease in Cell Potential (RDCP) were executed to evaluate the performance and stability of the system during waste conversion, followed by the characterization of yeast biofilms formed at the anode using a Scanning Electron Microscope (SEM). Conversely, the role of biofilms in sugarcane bagasse application, and the correlation with electricity generation was also studied. This contributes to the understanding and possible management of lignocellulosebased waste utilization, in order to create more practical, effective, and efficient strategies, using an integrated method with MFC and fermentation processes.

\section{Materials and Methods}

\subsection{Lignocellulosic Biomass}

Sugarcane bagasse was collected from sugarcane juice sellers, most of which were located in Serpong, South Tangerang, Indonesia, in November 2019. Bagasse, composed of $35 \%$ of 
cellulose, $32 \%$ of hemicellulose and $33 \%$ of lignin, was cut into small pieces and dried under the sun for three days to eliminate the water content. They were then placed in a sealed plastic bag at a temperature of $25^{\circ} \mathrm{C}$ before the time of use.

\subsection{MFC Reactor Architecture and Operation}

Two identical single-chamber cubic reactors made of plexiglass were used in MFCs with an active volume of $28 \mathrm{~mL}$, while a plain carbon with a projected surface area of $7 \mathrm{~cm}^{2}$ was used as both anode and cathode. In addition, Nafion 117 ( $3 \% \mathrm{w} / \mathrm{w} \mathrm{H}_{2} \mathrm{O}_{2}, 0.5 \mathrm{M} \mathrm{H}_{2} \mathrm{SO}_{4}$, and DI water) was used as a separator between the two electrodes, acting as a proton diffusion area. Initially, the raw materials for the LF process integrated with MFC consist of a mixture of dry bagasse and distilled water at a ratio of 1:10, which was then homogenized for 60 seconds to form slurry using PHILLIPS HR2056. The slurry was then filtered using a cheese cloth to separate the extract and the fibers. The sugarcane bagasse extract contained $12000 \mathrm{ppm}$ of glucose after analyzed using glucose sensor Gluco Dr AGM-2100 (Gyeonggi-do, South Korea). The sugarcane bagasse extract was subsequently added to $14 \mathrm{mg} / \mathrm{L}$ of commercial baker's yeast Saccharomyces cerevisiae (Lessafre, Marcq-en-Baroeul, France), adopted as a biocatalyst, and incubated semi-aerobically [4245], and then the copper wire was used to complete the circuit, followed by the application of $100 \mathrm{~W}$ external resistance. The system was operated in batch mode at $27{ }^{\circ} \mathrm{C}$ for three days (72 hours) per cycle, for a total of four cycles, where the voltage and current density were monitored during the incubation time. In the first three stages, the medium used was replaced by fresh bagasse slurry, containing yeast, while the anolyte in the fourth cycle was devoid of yeast. A contrast will be made with the S-SSF integration with MFC, where bagasse slurry was used as an anolyte without any filtration process.

\subsection{Electrochemical and Chemical Analysis}

The current and voltage density output during incubation process $(4 \times 72$ hours) are the main parameters used to evaluate the performance of MFC. This involved collecting the record of differences in closed circuit voltage (CCV) and current, using a digital multi-meter UNI-T UT61E, followed by the calculation of current density $\left(\mathrm{mA} / \mathrm{m}^{2}\right)$ by dividing the generated current by the anodic surface area $\left(\mathrm{m}^{2}\right)$. Furthermore, manual polarization was per- formed to evaluate MFC behavior, using a resistor set-up of Elenco RS-500, which was set within a range of $5 \mathrm{MW}$ to $100 \mathrm{~W}$. The resulting performance in terms of treatment efficiency was monitored by analyzing COD, conductivity, and the $\mathrm{pH}$ of anolyte, using Lutron WA2015.

\subsection{Morphology Analysis}

A JEOL JED-2300 was used to classify electrode surface morphology using SEM images and EDX to confirm biofilm formation. The SEM device was equipped with an energy dispersive X-ray spectroscopy (EDX) unit to verify the composition of the surface of the anode. The samples, consisting of pre-and postincubation anodes, were prepared by applying a carbon felt electrode to a carbon-coated twosided conductive adhesive tape to increase conductivity. SEM photographs were also obtained to ensure the presence of biofilms on electrode surfaces.

\section{Results and Discussion}

\subsection{Mechanism of Semi Fermentation}

Initially, glucose extracted from sugarcane bagasse is consumed by the yeast $S$. cerevisiae and converted to pyruvate via the glycolysis process, which requires several steps. This involves glyceraldehyde oxidation, where glycerol and phosphoenolpyruvate are formed, with tremendous bonding energy and ATP moles responding to the formation of pyruvate [46]. Decarboxylation is then accompanied by the generation of acetaldehyde, which is converted to acetic acid under aerobic conditions, while alcohol is released in the presence of minimal oxygen as the reaction reaches the anaerobic pathway [47].

The compounds formed by the glycolysis process, which are presented in the form of pyruvate, appear to enter the oxidative decarboxylation stage and eventually proceed to the preparation reaction before entering the Krebs cycle. These compounds are then converted to acetyl-CoA in the cytosol through acetaldehyde by releasing $\mathrm{CO}_{2}$, which then responds to the production of acetic acid. This is an oxidation process, characterized by the release of electrons, which allows the carbon atom to decline and thus transforms acetate to acetyl-CoA, which is later used in the Krebs or Tricarboxylic Acid (TCA) cycles. This includes the activation of Electron Transfer Chain (ETC) processes using high-energy molecules where the redox reactions of NAD/NADH, ADP/ATP, and 
FAD/FADH2 occurred. Several moles of electrons and protons are then formed, which pass through the mitochondria and are subsequently caught by the endogenous mediator. This substance operates from the cell to the electrode surface and acts as evidence of a lower yield of anaerobic microorganism cells compared to aerobics.

The mechanism in the semi-solid state process is very similar to the liquid fermentation process mentioned above, as some of the acetic acid formed can be used in hemicellulose hydrolysis in simpler forms of xylitol [25]. However, due to the comparatively limited concentration, this method was not very successful. This is consistent with studies by Pandey et al. [48] which showed the weak efficacy of yeast in lignocellulose hydrolysis and hence the need for genetic mutations. S. cerevisiae also contains a limited number of cellulose enzymes that can degrade cellulose into simpler pieces that can be transformed into energy, but not significant [49].

\subsection{Electrochemical Characteristic of Yeast MFC}

3.2.1 Voltage, current density, and power density

In this study, the MFC was inoculated with yeast $S$. cerevisiae as a biocatalyst, with the expectation of degrading substrate, which serves as a source of carbon and nitrogen in the production of electrical energy using both LF and S-SSF process. The initiation of these processes features stagnant electrical voltage, which tends to decrease over the first 50 hours. This was considered as the microorganisms' adaptation phase, characterized by the absence of yeast biofilm formation on the anode surface, followed by a marked increase in cell potential, up to the $72^{\text {nd }}$ hour. At this stage, the voltage reaches $5 \mathrm{mV}$ at the closed-circuit voltage CCV (100 W), as shown in Figure 1a.

Conversely, the yeast development is initiated, as the process enters the logarithmic phase, characterized by the increased formation of microorganism biofilms on the surface of the electrodes, which further enhances the transfer of electron to the anode [21,50]. However, within the second (72 hours), and the third cycle (144 hours), the substrate and fresh yeast were inserted into the reactor as replacements, and the voltage recorded was more or less similar with the highest values observed in the $1^{\text {st }} \mathrm{cy}$ cle. This was considered as the maximum voltage produced by bagasse using liquid and semisolid state fermentation, although lag phases were not discovered in the $2^{\text {nd }}$ and $3^{\text {rd }}$ cycles. This is consistent with the previous studies demonstrating the absence of a lag phase after a refill with fresh media and substrates [5153].

The 4th cycle involved the introduction of substrate alone, without yeast as the replacement, which results in the production of slightly lower voltage, which was not significantly different from previous values. Therefore, it is concluded that the formed biofilm possesses the ability to independently convert substrate into electrical energy, without adding similar external biocatalysts. The results also showed the production of slightly higher voltage in MFC, utilizing liquid fermentation from sugarcane bagasse than in the semi-solid state, with a difference of about 1-1.5 mV, under CCV conditions.

Figure $1 \mathrm{~b}$ shows the current density recorded, using liquid and semi-solid state fermentation, and the trend observed very similar with voltage production. This involved an adaptation phase within the first 50 hours, where the yeast biofilm had not formed, followed by the production of fluctuating current density, with progressive decline. Furthermore, a logarithmic period is reached, where higher values of up to $305 \mathrm{~mA} / \mathrm{m}^{2}$ and $287 \mathrm{~mA} / \mathrm{m}^{2}$ were reached for MFC with liquid and semi-solid fermentation, respectively. Meanwhile, further increase up to values in the previous cycle was reported after the replacement of fresh media and microorganisms at the beginning of the $2^{\text {nd }}$ and $3^{\text {rd }}$ cycles, without any lag phase. Therefore, a reduction trend is observed subsequently, due to substrate depletion, which affects the conversion process to protons and electrons by yeast. In addition, the capture efficiency of electrode is vital in the reaction kinetics of MFCs, and the electron transfer rate also significantly affects the value of coulombic efficiency (CE). Meanwhile, the current density produced in the $4^{\text {th }}$ cycle demonstrates the formation of biofilms, which is necessary in the conversion process, despite the fact that external microorganisms were not added. Generally, the current density values produced by both raw materials were very similar in all cycles, on an average.

The average power density is obtained based on the measurements of voltage and current at each instance in time as shown in Figure 1c. The integration of MFC with liquid fermentation provided values of $1.13 \pm 0.23$ $\mathrm{mW} / \mathrm{m}^{2}$, which was slightly higher than $0.84 \pm 0.18 \mathrm{~mW} / \mathrm{m}^{2}$, recorded with the semi-solid state. The commencement of operation fea- 

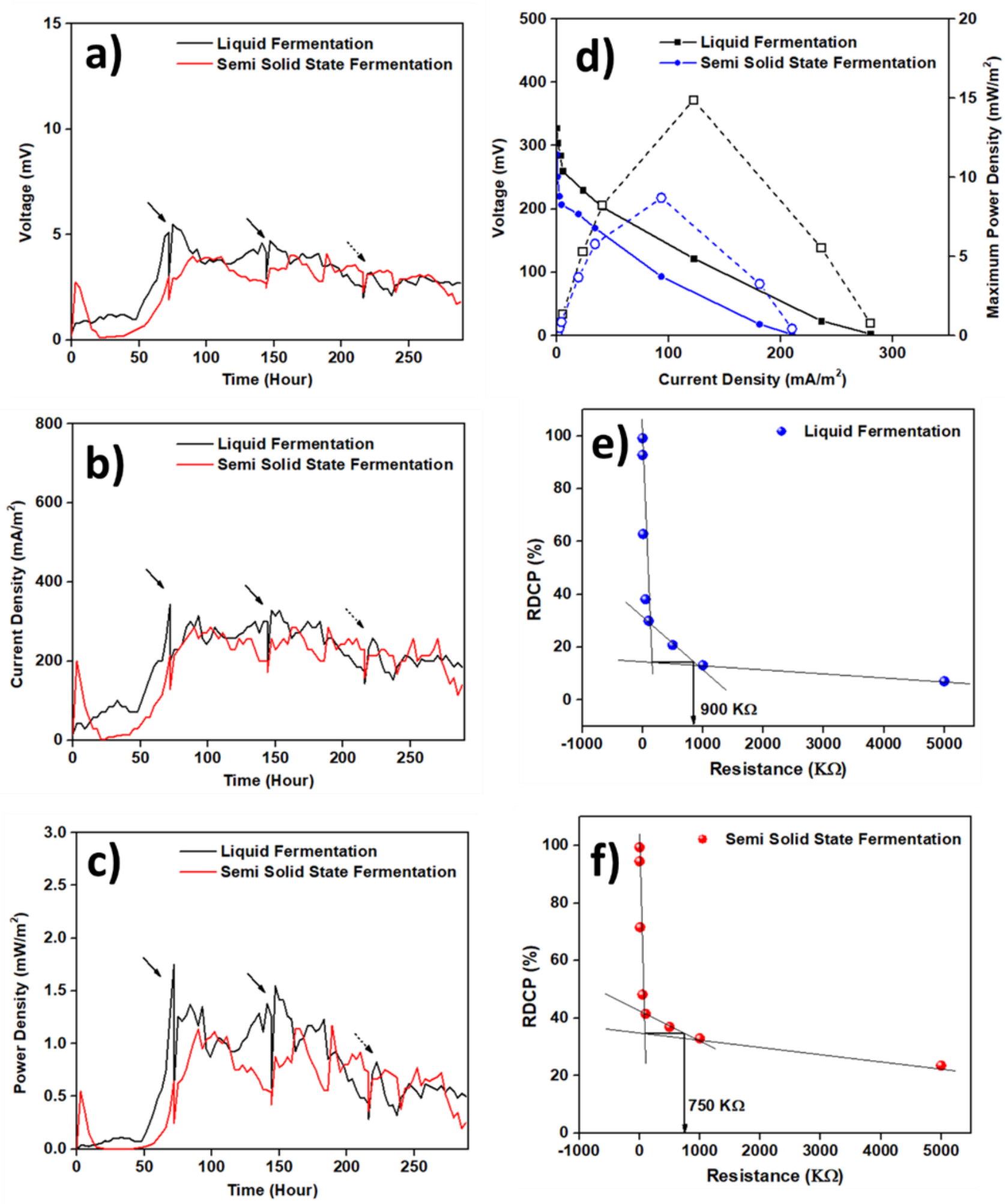

Figure 1. a) Voltage, b) current density and c) power density of MFC with liquid and semi-solid state fermentation process. However, d) shows the individual polarization and power curves, while e) and f) show the Relative Decrease in Cell Potential (RDCP). Solid arrows show fresh substrate and yeast replacement, while dash arrow shows only substrate replacement. 
tured the tendency to stagnate, which increase after 50 hours, and a similar trend was observed in the current density. Furthermore, the $2^{\text {nd }}$ and $3^{\text {rd }}$ rounds showed another increase in power density, shortly after a replacement with fresh media and microorganisms to the reactor. Subsequently, another decline is observed after the peak is reached, resulting from substrate depletion in the MFC system, although the power density recorded in the $4^{\text {th }}$ cycle is generally lower than all previous phases. This occurred because additional fresh microorganism was not added. In addition, the yeast was observed to only emanate from biofilm formed on the anode surface, from the first to the third cycles, consequently demonstrating the potential to generate electrical energy.

3.2.2 Maximum power density and relative decrease in cell potential

Figure 1d shows the polarization curves of yeast MFC integrated with LF and S-SSF. Therefore, cell voltage was calculated at different external resistances, followed by the computation of current and power density, according to the explanation in the previous section. In addition, the maximum power density (MPD) reached $14.88 \mathrm{~mW} / \mathrm{m}^{2}$ after applied external resistance of $10 \mathrm{KW}$ at a current density of $122 \mathrm{~mA} / \mathrm{m}^{2}$, for liquid fermentation. It was about 1.7-folds higher than MPD and current density for the solid-state, at $8.70 \mathrm{~mW} / \mathrm{m}^{2}$ and $93.3 \mathrm{~mA} / \mathrm{m}^{2}$, respectively.

It is crucial to determine the systems' internal resistance based on the slope of the polarization curve, and all values obtained were about 1463 and $160 \mathrm{~W}$ for LF and S-SSF, respectively. These values are in line with the reference range [7,54]. Also, the use of molasses as a substrate is known to produce higher MPD, compared to sugarcane bagasse, as Zhang et al. recorded a maximum value of $1410.2 \mathrm{~mW} / \mathrm{m}^{2}$ from the wastewater, using UASB-MFC-BAF system [55]. However, a study by Hassan et al. produced an MPD of $188.5 \mathrm{~mW} / \mathrm{m}^{2}$ [56], which was attributed to several factors, including (1) the presentation of molasses in a liquid form and the homogeneity with the electrolyte solution. This tends to increase the rate of substrate consumption by microorganisms and electron transfer. (2) molasses possesses more organic residue content than bagasse. (3) the activated sludge consisting of several types of microorganisms was used as a biocatalyst, which was certainly more concentrated than the yeast applied in the current research. Therefore, the resulting MPD was comparable with other studies, as shown in Table 1. This variation was influenced by

Table 1. Comparison of MPD with other MFC research

\begin{tabular}{|c|c|c|c|c|}
\hline Biocatalyst & Substrate & Configuration & $\begin{array}{l}\text { Max. Power } \\
\text { Density } \\
\left(\mathrm{mW} / \mathrm{m}^{2}\right) \\
\end{array}$ & Ref \\
\hline E. cloacae & cellulose & $\begin{array}{l}\text { two-chambered MFC; electrodes- } \\
\text { carbon cloth and carbon fiber; } \\
\text { catholyte: } \mathrm{K}_{3} \mathrm{Fe}(\mathrm{CN})_{6} \quad \text { two- } \\
\text { chambered MFC; electrodes: carbon } \\
\text { paper; catholyte: } \mathrm{K}_{3} \mathrm{Fe}(\mathrm{CN})_{6}\end{array}$ & 5.4 & {$[57]$} \\
\hline $\begin{array}{l}\text { Geobacter } \\
\text { sulfurreducens }\end{array}$ & cellulose & $\begin{array}{l}\text { two-chambered MFC; electrodes - } \\
\text { graphite fibers; catholyte: } \mathrm{K}_{3} \mathrm{Fe}(\mathrm{CN})_{6}\end{array}$ & 10 & {$[58]$} \\
\hline $\begin{array}{l}\text { Enterobacter } \\
\text { cloacae }\end{array}$ & Malt extract & $\begin{array}{l}\text { two-chambered MFC; electrodes - graph- } \\
\text { ite rods, graphite plates; mediator: me- } \\
\text { thyl viologen; catholyte: aerated PBS }\end{array}$ & 9.3 & [59] \\
\hline $\begin{array}{l}\text { Saccharomyces } \\
\text { cerevisiae }\end{array}$ & Glucose & $\begin{array}{l}\text { two-chambered MFC; electrodes - graph- } \\
\text { ite plates; catholyte: aerated water }\end{array}$ & 16 & {$[60]$} \\
\hline $\begin{array}{l}\text { Geobacter } \\
\text { metallireducens }\end{array}$ & Corncob & $\begin{array}{l}\text { one chambered; electrodes - graphite rod; } \\
\text { air cathode }\end{array}$ & 7.18 & {$[61]$} \\
\hline $\begin{array}{l}\text { Native bacteria } \\
\text { in activated } \\
\text { sludge }\end{array}$ & cellulose & $\begin{array}{l}\text { two-chambered MFC; graphite brush } \\
\text { and carbon paper; catholyte: aerated wa- } \\
\text { ter }\end{array}$ & 12 & {$[62]$} \\
\hline $\begin{array}{l}\text { Saccharomyces } \\
\text { cerevisiae }\end{array}$ & $\begin{array}{l}\text { agricultural } \\
\text { and livestock } \\
\text { industry waste }\end{array}$ & $\begin{array}{l}\text { two-chambered MFC; electrodes - carbon } \\
\text { paper and carbon plate }\end{array}$ & 5.1 & {$[63]$} \\
\hline
\end{tabular}


the nature of microorganisms used as biocatalyst, membrane separator, electrode material, and the MFC system architecture, assumed to have a direct effect on the results.

The maximum sustainable electricity generated in a system on external loads indicates fuel cell efficiency [64]. Meanwhile, surface anode potential is one of the elements used to determine bacterial energy acquisition from a thermodynamic perspective [65]. This was identified as the point where bacteria obtain more energy and facilitate extracellular electron transfer, based on the terminal electron acceptor capacity [66]. In addition, the Relative Decrease in Cell Potential (RDCP) is a new approach adapted from Relative Decrease in Anode Potential (RDAP). RDAP is a function of external resistance which is applied to evaluate the maximum sustainability of MFC, based on the ability to generate electricity [67]. The results are shown in Figure 1 e-f were $900 \mathrm{k} \Omega$ and $750 \mathrm{k} \Omega$, obtained using liquid and semi-
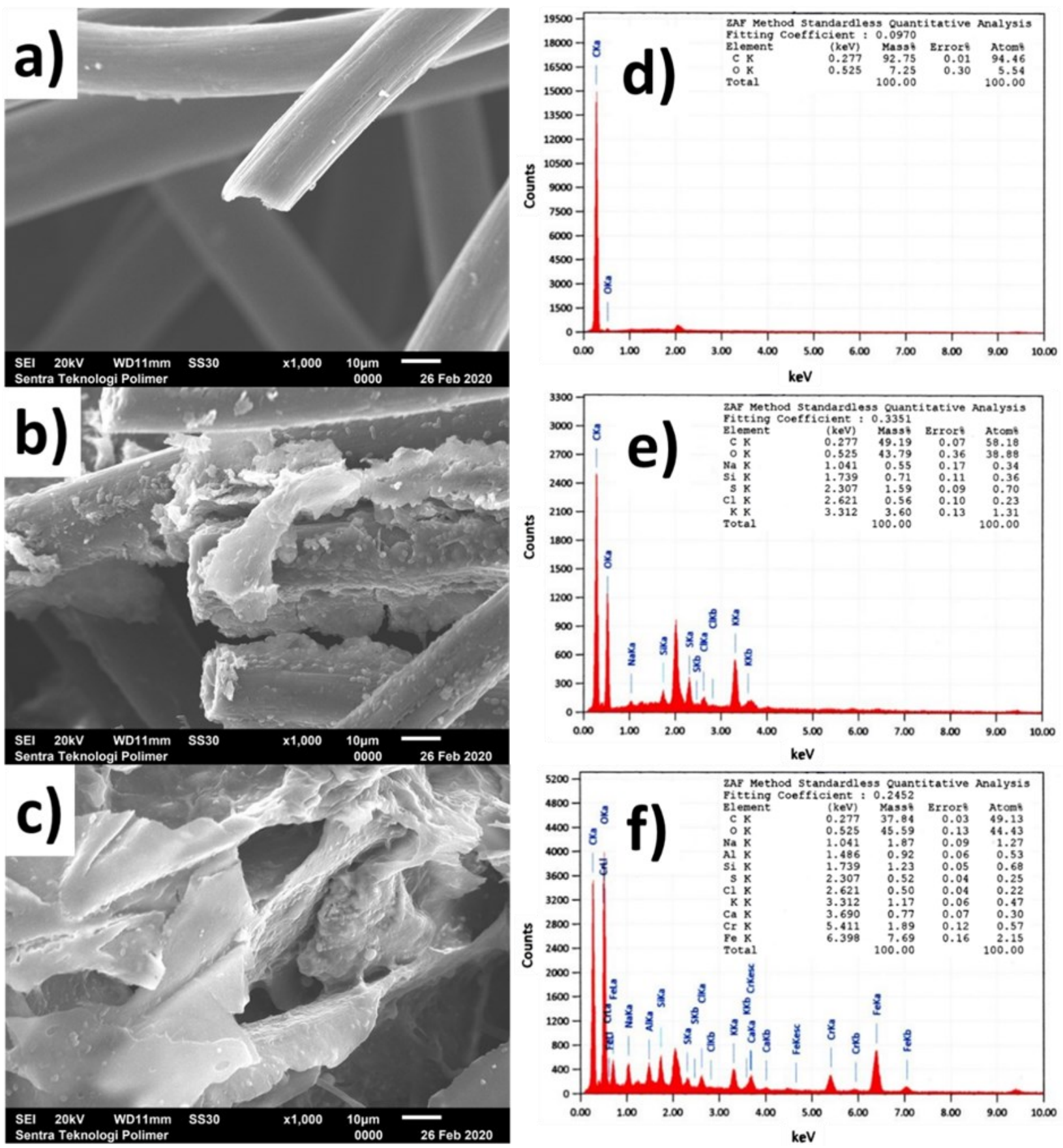

Figure 2. SEM images of MFC's anode a) before and after incubation process with b) liquid and c) semisolid state fermentation, while d) - f) show the EDX measurement, respectively. 
solid state fermentation, respectively. Therefore, the conditions at the cathode for both systems are considered to be similar, with potential that is proportional to the resistance, while a higher oxidation tendency at the anode provides more energy from the biocatalyst activity [68]. This is particularly associated with the ability for the microorganism to adapt, especially when there is faster electron release, which contributes to higher electricity and energy generation.

\subsection{Biofilm Formation in the Anode of MFC Yeast}

Figure 2a-c demonstrates the anode morphology before and after incubation with the liquid and semi-solid state fermentation method. This involved three phases, including (1) an initially visible plain carbon fiber without biofilms (Figure 2a). (2), the appearance of numerous spots, indicating an interaction between yeast and carbon fiber (Figure 2b). This surface manifestation was also covered by exopolysaccharides, which denote the formation of biofilm layer, characterized by high conductivity, needed to accelerate the rate of electron transfer from yeast to the anode surface. The ease of movement is facilitated using pili, on instances when the biofilm is available. (3) Figure 2c shows the sugarcane bagasse fibers as slightly flattened, which adds to the fiber in the carbon felt, although yeast developed better attachment with the sugarcane surface. This is proof of adverse effects on the production rates of electricity, as shown by the results of the electrochemical characterization observed in the previous section. The MFCs with liquid fermentation tend to generate more effectively, with higher amounts than the semi-solid state. In addition, wider distance between the surface of the anode and the yeast, leads to difficulties in the transfer of electrons, despite the existence of a biofilm.

Figures $2 \mathrm{~d}$-f shows the analysis of the elements in the anode before and after incubation during the MFC process, with both liquid and semi-solid state fermentation. The results are demonstrated in plain carbon felt (Figure 2d), where the dominant elements include Carbon $(92.75 \%)$ as the main component, and oxygen $(7.25 \%)$, which is present because of the fabrication/synthesis process. In addition, elements other than carbon (49.19\%) and oxygen $(43.79 \%)$ were detected at the anode after the incubation process, after the liquid fermentation method (Figure 2e). These include sodium $(0.55 \%)$, silicon $(0.71 \%)$, sulphur $(1.59 \%)$, chlo- rine $(0.56 \%)$, and potassium (3.60\%), where sulfur and potassium indicate the presence of a yeast biofilm, known to be the metabolism result [69]. Meanwhile, the increase in $\mathrm{O}$ shows the presence of exo-polysaccharide, being the main constituent of biofilm, which is congruent with the results of SEM characterization, where yeast attaches to carbon fiber surfaces and then form biofilms. The elements of carbon (37.59\%), oxygen (45.59\%), sodium (1.87\%), aluminum (0.92\%), silicon (1.23\%), sulphur $(0.52 \%)$, chlorine $(0.50 \%)$, potassium $(1.17 \%)$, calcium (0.77\%), chromium (1.89\%), iron (7.69\%) were identified at the anode of MFC integrated with semi-solid state fermentation (Figure 2f). Therefore, the elevated mass percentage of oxygen, which is higher than carbon, correlates with the presence of lignocellulose attached to the surface of the carbon felt. Additionally, the sodium, aluminum, silicon, chlorine, calcium, chromium, and iron suggest the entry of impurities, while the decreased amount of sulphur and potassium denotes a deficiency in yeast biofilm formation, based on the semi-solid state fermentation.

\subsection{Organics Removal, $\mathrm{pH}$, and Conductivity during the Incubation Process}

Figure $3 \mathrm{a}$ is a highlight of substrate degradation, which demonstrates the removal of COD in sugarcane bagasse, using the liquid and semi-solid state fermentation method. Conversely, the microenvironment tends to influence substrate degradation ability, while other external factors include the operating conditions, and behavior of biocatalyst. In addition, electrogenesis has been identified as one of the parameters used to measure the effect and extent of microorganism degradation activity on substrate, during the production of protons and electrons. The depletion in microbial fuel cells was evaluated regularly within a time interval of 72 hours, which was considered as 1 cycle.

In the batch experiments, there was a continuous increase in the removal of COD in each cycle, using liquid fermentation system. Furthermore, the first cycle (first 3 days) led to about $36.36 \%$ decline from $14700 \mathrm{mg} / \mathrm{L}$ to 9355 $\mathrm{mg} / \mathrm{L}$, which gradually increased by 46.21 , 37.88 , and 38.26, in the second, third, and fourth cycle, respectively. Conversely, the records from the semi-solid state reached $26.25 \%$ from $15000 \mathrm{mg} / \mathrm{L}$ to $11062 \mathrm{mg} / \mathrm{L}$, and an increase in percentage was observed in the second and third cycles, which declined during the fourth, at $30.12 \%, 31.88 \%$, and $27.50 \%$, respec- 
tively. This reduction was attributed to the formation of very few biofilms, following the replacement with substrate, which was free-form yeast. However, the amount of removed materials was higher than the results conducted by Hassan et al. using a culture of cellulose as a substrate in two-chambered MFCs, where $29.33 \%$ was recorded after ten days of operation [7]. Hence, the production of bioelectricity from sugarcane bagasse shows the organic component biodegradability, and also the consumption tendency by of yeast $S$. cerevisiae is needed to stimulate the conversions needed.

Figure $3 \mathrm{~b}$ shows the $\mathrm{pH}$ variation of yeast MFCs with semi-solid state and liquid fermentation, which was lower in the latter, with an average value of \pm 0.14 . This occurred because of acetic acid production in semi-aerobic conditions, which is then transformed into acetyl coA, required in the Krebs cycle, and prolonged exposure rates lead to further accumulation of acetic acid. Moreover, the reduced $\mathrm{pH}$ was also
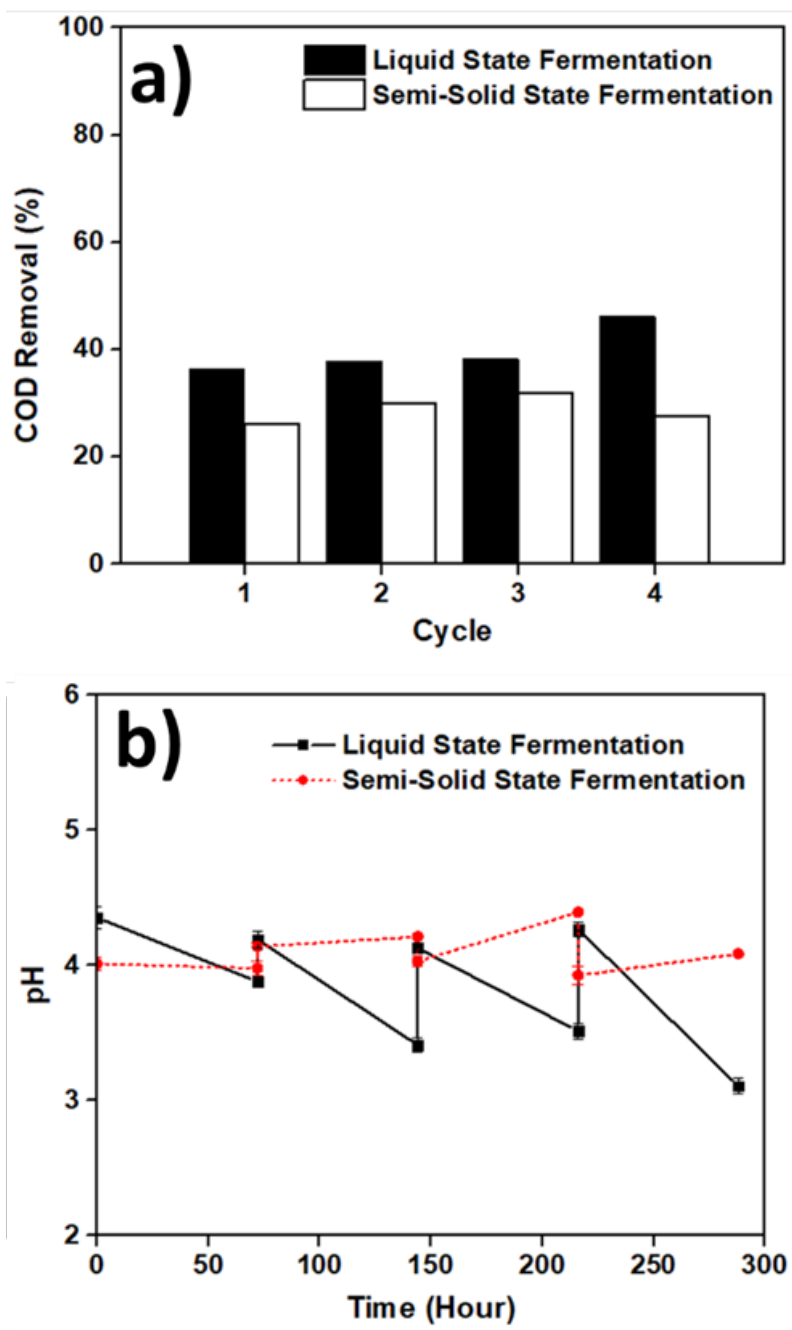

affiliated with the accumulation of protons $\left(\mathrm{H}^{+}\right)$ in the anode chamber, due to the slower rate of protons migration to the cathode chamber through the separating membrane. Conversely, the $\mathrm{pH}$ in semi-solid state fermentation was slightly increased in each subsequent cycle, with an average of \pm 0.09 . This manifestation was associated with three factors, including: (1) the use of acetic acid to degrade lignocellulose [25], followed by the absence of acid accumulation in the system; (2) The lignocellulose reduction activity of yeast during the formation of simple compounds requires a relatively long time of exposure, which is needed to produce sufficient nitrogen waste needed for the generation of higher $\mathrm{pH}[70,71]$; (3) The acetate was widely used in the degradation process, rather than being converted to acetyl Co-A, hence the Krebs cycle was sub-optimal, and followed by the production of a few protons. These subsequently accumulated to quantities that were relatively lower than nitrogen waste, leading to a continuous increase $\mathrm{pH}$, despite the fact that protons were in the anode chamber.

The conductivity of electrolyte is vital in MFC, being one of the factors influencing the rate of electron transfer from microorganisms to anode. Figure 3c shows an increase in electrolyte conductivity on the anode side (anolyte), with a value of $2 \mu \mathrm{S} / \mathrm{cm}$, following the fermentation process. This upsurge occurred because of proton accumulation, which indirectly affects the rate of electron transfer from microbes to anode and subsequently to the cathode, through the external circuit. However, a shortage in protons required for the Oxygen Reduction Reaction (ORR) process was reported at the cathode, which resulted in lower voltage, as well as current and power density.

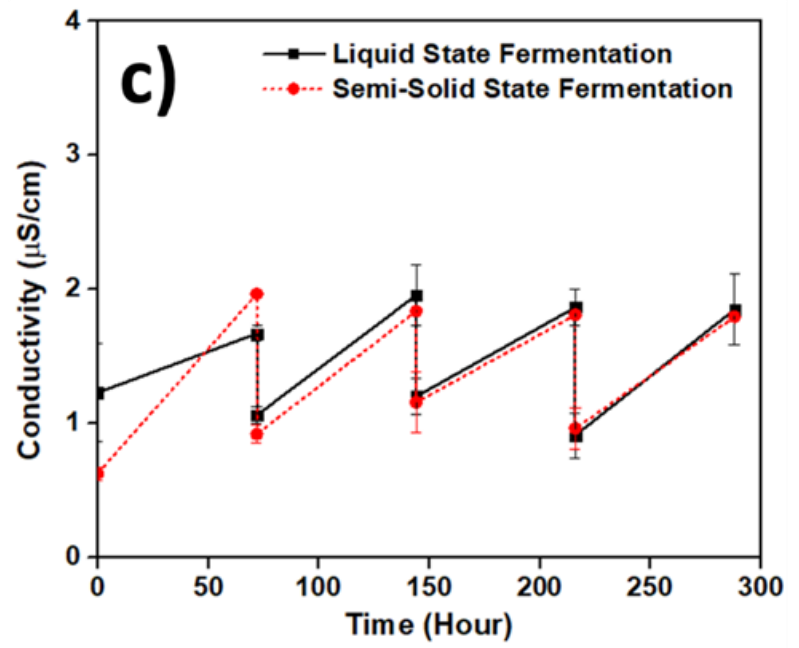

Figure 3. a) COD removal, b) $\mathrm{pH}$ and c) electrical conductivity of MFC's anolyte during incubation with liquid and semi-solid state fermentation process. 


\section{Conclusion}

This research shows the performance of the MFC system integrated with the fermentation of sugarcane bagasse to generate electricity directly by using Saccharomyces cerevisiae. The maximum power density of $14.88 \mathrm{~mW} / \mathrm{m}^{2}$ and $8.70 \mathrm{~mW} / \mathrm{m}^{2}$ was achieved using $\mathrm{LF}$ and $\mathrm{S}-\mathrm{SSF}$, with an average COD removal per cycle of 39.68 and $28.94 \%$, respectively. In addition, the $\mathrm{pH}$ decreased after liquid fermentation due to the presence of acid during yeast metabolism. However, due to the effects of nitrogen waste created by the lignocellulose degradation process, a slightly increased $\mathrm{pH}$ value was observed in the semi-solid state. The results above show that the integration of MFC systems with LF results in more impressive performance than S-SSF. The presence of fibers in the process of S-SSF makes the distance between the yeast and the electrode surface, with the purpose of the electron transfer process was slow.

\section{Acknowledgments}

This project was fully supported by the $\mathrm{Hi}$ bah Penelitian Dasar 2021 given by the Ministry of Research and Technology/National Research and Innovation Agency Republic of Indonesia. Authors would like to thank Misbakhul Munir and Elvando Wijaya Putra from the Department of Chemical Engineering - Institut Teknologi Indonesia for their assistance in collecting data.

\section{References}

[1] Jia, J., Tang, Y., Liu, B., Wu, D., Ren, N., Xing, D. (2013). Electricity generation from food wastes and microbial community structure in microbial fuel cells. Bioresource Technol., $144, \quad 94-99, \quad \mathrm{do}$ i : 10.1016/j.biortech.2013.06.072

[2] Chen, Y., Luo, J., Yan, Y., Feng, L. (2013). Enhanced production of short-chain fatty acid by co-fermentation of waste activated sludge and kitchen waste under alkaline conditions and its application to microbial fuel cells. Appl. Energy., 102, 1197-1204, doi: 10.1016/j.apenergy.2012.06.056

[3] Sevda, S., Dominguez-Benetton, X., Vanbroekhoven, K., De Wever, H., Sreekrishnan, T.R., Pant, D. (2013). High strength wastewater treatment accompanied by power generation using air cathode microbial fuel cell. Appl. Energy, 105, 194-206, doi: 10.1016/j.apenergy.2012.12.037
[4] Logan, B.E., Hamelers, B., Rozendal, R., Schröder, U., Keller, J., Freguia, S., Aelterman, P., Verstraete,W., Rabaey, K. (2006). Microbial fuel cells: methodology and technology. Environ. Sci. Technol., 40, 5181-5192, doi: 10.1021/es0605016

[5] Logan B.E., Regan, J.M. (2006). Microbial fuel cells-challenges and applications. Environ. Sci. Technol., 40, 5172-5180, doi: 10.1021/es0627592

[6] Liu, H., Cheng, S., Logan, B.E. (2005). Production of electricity from acetate or butyrate using a single-chamber microbial fuel cell. Environ. Sci. Technol., 39, 658-662, doi: 10.1021/es048927c

[7] Hassan, S.H., Kim, Y.S., Oh, S.E. (2012). Power generation from cellulose using mixed and pure cultures of cellulose-degrading bacteria in a microbial fuel cell. Enzyme Microb. Technol., 51, 269-273, doi: 10.1016/j.enzmictec.2012.07.008

[8] Logan, B.E., Murano, C., Scott, K., Gray, N.D., Head, I.M. (2005). Electricity generation from cysteine in a microbial fuel cell. $W a$ ter Res., 39, 942-952, doi: 10.1016/j.watres.2004.11.019

[9] Rezaei, F., Richard, T.L., Brennan, R.A., Logan, B.E. (2007). Substrate-enhanced microbial fuel cells for improved remote power generation from sediment-based systems. Environ. Sci. Technol., 41, 4053-4058, doi: 10.1021/es070426e

[10] Rabaey, K., Ossieur, W., Verhaege, M., Verstraete, W. (2005). Continuous microbial fuel cells convert carbohydrates to electricity. $W a-$ ter Sci. Technol., 52, 515-523, doi: 10.2166/wst.2005.0561

[11] Zuo, Y., Maness, P.C., Logan. B.E. (2006). Electricity production from steam-exploded corn stover biomass. Energy Fuels, 20, 17161721, doi: 10.1021/ef0600331

[12] Hadiyanto, H., Christwardana, M., da Costa, C. (2019). Electrogenic and biomass production capabilities of a Microalgae-Microbial fuel cell (MMFC) system using tapioca wastewater and Spirulina platensis for COD reduction. Energy Sources Part A., 1-12, doi: 10.1080/15567036.2019.1668085

[13] Lovley, D.R., \& Phillips, E.J. (1988). Novel mode of microbial energy metabolism: organic carbon oxidation coupled to dissimilatory reduction of iron or manganese. Appl. Environ. Microbiol., 54, 1472-1480.

[14] Christwardana, M., Kwon, Y. (2017). Yeast and carbon nanotube based biocatalyst developed by synergetic effects of covalent bonding and hydrophobic interaction for performance enhancement of membraneless microbial fuel 
cell. Bioresource Technol., 225, 175-182, doi: 10.1016/j.biortech.2016.11.051

[15] Schilirò, T., Tommasi, T., Armato, C., Hidalgo, D., Traversi, D., Bocchini, S., Gilli, G., Pirri, C.F. (2016). The study of electrochemically active planktonic microbes in microbial fuel cells in relation to different carbon-based anode materials. Energy, 106, 277-284, doi: 10.1016/j.energy.2016.03.004

[16] Bond, D.R., Lovley, D.R. (2005). Evidence for involvement of an electron shuttle in electricity generation by Geothrix fermentans. Appl. Environ. Microbiol., 71, 2186-2189, doi: 10.1128/AEM.71.4.2186-2189.2005

[17] Esmaeili, C., Ghasemi, M., Heng, L.Y., Hassan, S.H., Abdi, M.M., Daud, W.R.W., Ilbeygi, H., Ismail, A.F. (2014). Synthesis and application of polypyrrole/carrageenan nano-bio composite as a cathode catalyst in microbial fuel cells. Carbohydrate Polym., 114, 253-259, doi: 10.1016/j.carbpol.2014.07.072

[18] Ghasemi, M., Daud, W.R.W., Ismail, M., Rahimnejad, M., Ismail, A.F., Leong, J.X., Miskan, M., Liew, K.B. (2013). Effect of pretreatment and biofouling of proton exchange membrane on microbial fuel cell performance. Int. J. Hydrogen Energy, 38, 5480-5484, doi: 10.1016/j.ijhydene.2012.09.148

[19] Liu, H., Cheng, S., Huang, L., Logan, B.E. (2008). Scale-up of membrane-free singlechamber microbial fuel cells. J. Power Sources, $179, \quad 274-279$, doi: 10.1016/j.jpowsour.2007.12.120

[20] Rahimnejad, M., Adhami, A., Darvari, S., Zirepour, A., Oh, S.E. (2015). Microbial fuel cell as new technology for bioelectricity generation: a review. Alex. Eng. J., 54, 745-756, doi: 10.1016/j.aej.2015.03.031

[21] Santoro, C., Arbizzani, C., Erable, B., Ieropoulos, I. (2017). Microbial fuel cells: from fundamentals to applications. A review. J. Power Sources, $356, \quad 225-244$, doi: 10.1016/j.jpowsour.2017.03.109

[22] Petrus, L., Noordermeer, M.A. (2006). Biomass to biofuels, a chemical perspective. Green Chem., 8, 861-867, doi: 10.1039/B605036K

[23] Ragauskas, A.J., Nagy, M., Kim, D.H., Eckert, C.A., Hallett, J.P., Liotta, C.L. (2006). From wood to fuels: integrating biofuels and pulp production. Ind. Biotechnol., 2, 55-65, doi: 10.1089/ind.2006.2.55

[24] Popescu, M.C., Popescu, C.M., Lisa, G., Sakata, Y. (2011). Evaluation of morphological and chemical aspects of different wood species by spectroscopy and thermal methods. $J$. Mol. Struct., 988, 65-72, doi: 10.1089/ind.2006.2.55
[25] Trzcinski, A.P., Stuckey, D.C. (2015). Contribution of acetic acid to the hydrolysis of lignocellulosic biomass under abiotic conditions. Bioresource Technol., 185, 441-444, doi: 10.1016/j.biortech.2015.03.016

[26] ElMekawy, A., Diels, L., De Wever, H., Pant, D. (2013). Valorization of cereal based biorefinery byproducts: reality and expectations. Environ. Sci. Technol., 47, 9014-9027, doi: $10.1021 / \mathrm{es} 402395 \mathrm{~g}$

[27] Philippidis G.P. (2018). Cellulose bioconversion technology. In Handbook on Bioethanol. London: Routledge; pp. 253-285.

[28] Ahmad, F., Atiyeh, M.N., Pereira, B., Stephanopoulos, G.N. (2013). A review of cellulosic microbial fuel cells: performance and challenges. Biomass Bioenergy, 56, 179-188, doi: 10.1016/j.biombioe.2013.04.006

[29] Mosier, N., Wyman, C., Dale, B., Elander, R., Lee, Y.Y., Holtzapple, M., Ladisch, M. (2005). Features of promising technologies for pretreatment of lignocellulosic biomass. Bioresource Technol., 96, 673-686, doi: 10.1016/j.biortech.2004.06.025

[30] Yang, B., Wyman, C.E. (2008). Pretreatment: the key to unlocking low-cost cellulosic ethanol. Biofuels Bioprod. Biorefin., 2, 26-40, doi: 10.1002/bbb.49

[31] Krishnaraj, R.N., Berchmans, S., Pal, P. (2015). The three-compartment microbial fuel cell: a new sustainable approach to bioelectricity generation from lignocellulosic biomass. Cellulose, 22, 655-662, doi: 10.1007/s10570-014-0463-4

[32] Pandey, A., Soccol, C.R., Nigam, P., Soccol, V.T. (2000). Biotechnological potential of agro-industrial residues. I: sugarcane bagasse. Bioresource Technol., 74, 69-80, doi: 10.1016/S0960-8524(99)00142-X

[33] Dias, M.O., Junqueira, T.L., Cavalett, O., Pavanello, L.G., Cunha, M.P., Jesus, C.D.F., Filho, R.M., Bonomi, A. (2013). Biorefineries for the production of first and second generation ethanol and electricity from sugarcane. Appl. Energy, 109, 72-78, doi: 10.1016/j.apenergy.2013.03.081

[34] Rainey, T.J., Covey, G. (2016). Pulp and paper production from sugarcane bagasse. John Wiley \& Sons, Inc., New Jersey.

[35] Singh, K., Kumar, R., Chaudhary, V., Vaishali, Sunil, Arya, A.M., and Sharma, S. (2019). Sugarcane bagasse: Foreseeable biomass of bio-products and biofuel: An overview. $J$. Pharmacog. Phytochem., 8, 2356-2360

[36] Sindhu, R., Gnansounou, E., Binod, P., Pandey, A. (2016). Bioconversion of sugarcane crop residue for value added products - An 
overview. Renew. Energy, 98, 203-215, doi: 10.1016/j.renene.2016.02.057

[37] Dávila, J.A., Hernández, V., Castro, E., Cardona, C.A. (2014). Economic and environmental assessment of syrup production. Colombian case. Bioresource Technol., 161, 84-90, doi: 10.1016/j.biortech.2014.02.131

[38] Schaetzle, O., Barrière, F., Baronian, K. (2008). Bacteria and yeasts as catalysts in microbial fuel cells: electron transfer from microorganisms to electrodes for green electricity. Energy Environ. Sci., 1, 607-620, doi: 10.1039/B810642H

[39] Hubenova Y., Mitov, M. (2015). Extracellular electron transfer in yeast-based biofuel cells: A review. Bioelectrochemistry, 106, 177-185, doi: 10.1016/j.bioelechem.2015.04.001

[40] Rossi, R., Cavina, M., Setti, L. (2016). Characterization of electron transfer mechanism in mediated microbial fuel cell by entrapped electron mediator in saccharomyces cerevisiae. Chem. Eng. Trans., 49, 559-564, doi: 10.3303/CET1649094

[41] Rossi, R., Fedrigucci, A., Setti, L. (2015). Characterization of electron mediated microbial fuel cell by Saccharomyces cerevisiae. Chem. Eng. Trans., 43, 337-342, doi: 10.3303/CET1543057

[42] Christwardana, M., Frattini, D., Accardo, G., Yoon, S.P., Kwon, Y. (2018). Optimization of glucose concentration and glucose/yeast ratio in yeast microbial fuel cell using response surface methodology approach. J. Power Sources, $402, \quad 402-412$, doi: 10.1016/j.jpowsour.2018.09.068

[43] Christwardana, M., Frattini, D., Accardo, G., Yoon, S.P., Kwon, Y. (2018). Effects of methylene blue and methyl red mediators on performance of yeast based microbial fuel cells adopting polyethylenimine coated carbon felt as anode. J. Power Sources, 396, 1-11, doi: 10.1016/j.jpowsour.2018.06.005

[44] Christwardana, M., Frattini, D., Accardo, G., Yoon, S.P., Kwon, Y. (2018). Early-stage performance evaluation of flowing microbial fuel cells using chemically treated carbon felt and yeast biocatalyst. Appl. Energy, 222, 369-382, doi: 10.1016/j.apenergy.2018.03.193

[45] Christwardana, M., Frattini, D., Duarte, K.D., Accardo, G., Kwon, Y. (2019). Carbon felt molecular modification and biofilm augmentation via quorum sensing approach in yeast-based microbial fuel cells. Appl. Energy, $238, \quad 239-248, \quad$ d o i : 10.1016/j.apenergy.2019.01.078

[46] Hynne, F., Danø, S., Sørensen, P.G. (2001). Full-scale model of glycolysis in Saccharomyces cerevisiae. Biophys. Chem., 94(1-2), 121163, doi: 10.1016/S0301-4622(01)00229-0
[47] Li, Y., He, D., Niu, D., Zhao, Y. (2015). Acetic acid production from food wastes using yeast and acetic acid bacteria micro-aerobic fermentation. Bioproc. Biosys. Eng., 38(5), 863-869. doi: 10.1007/s00449-014-1329-8

[48] Pandey, A.K., Kumar, M., Kumari, S., Kumari, P., Yusuf, F., Jakeer, S., Naz, S., Chandna, P., Bhatnagar, I., Gaur, N.A. (2019). Evaluation of divergent yeast genera for fermentation-associated stresses and identification of a robust sugarcane distillery waste isolate Saccharomyces cerevisiae NGY10 for lignocellulosic ethanol production in SHF and SSF. Biotechnol. Biofuels, 12, 40, doi: 10.1186/s13068-019-1379-x

[49] Lee, C.R., Sung, B.H., Lim, K.M., Kim, M.J., Sohn, M.J., Bae, J.H., Sohn, J.H. (2017). Cofermentation using recombinant Saccharomyces cerevisiae yeast strains hyper-secreting different cellulases for the production of cellulosic bioethanol. Sci. Rep., 7, 1-14, doi: 10.1038/s41598-017-04815-1

[50] Christwardana, M., Handayani, A.S., Yudianti, R., Joelianingsih, J. (2021). Cellulose - Carrageenan Coated Carbon Felt as Potential Anode Structure for Yeast Microbial Fuel Cell. Int. J. Hydrogen Energy, 46, 6076-6086, doi:10.1016/j.ijhydene.2020.05.265

[51] Huang, L., Zeng, R.J., Angelidaki, I. (2008). Electricity production from xylose using a mediator-less microbial fuel cell. Bioresource Technol., 99, 4178-4184, doi: 10.1016/j.biortech.2007.08.067

[52] Zhang, B., Zhao, H., Zhou, S., Shi, C., Wang, C., Ni, J. (2009). A novel UASB-MFC-BAF integrated system for high strength molasses wastewater treatment and bioelectricity generation. Bioresource Technol., 100, 56875693, doi: 10.1016/j.biortech.2009.06.045

[53] Kim, B.H., Park, H.S., Kim, H.J., Kim, G.T., Chang, I.S., Lee, J., Phung, N.T. (2004). Enrichment of microbial community generating electricity using a fuel-cell-type electrochemical cell. Appl. Microbiol. Biotechnol., 63, 672681, doi: 10.1007/s00253-003-1412-6

[54] Ghasemi, M., Daud, W.R.W., Hassan, S.H., Jafary, T., Rahimnejad, M., Ahmad, A., Yazdi, M.H. (2016). Carbon nanotube/polypyrrole nanocomposite as a novel cathode catalyst and proper alternative for $\mathrm{Pt}$ in microbial fuel cell. Int. J. Hydrogen Energy, $41, \quad 4872-4878, \quad$ d o i : 10.1016/j.ijhydene.2015.09.011

[55] Zhang, Y., Min, B., Huang, L., Angelidaki, I., (2009). Generation of electricity and analysis of microbial communities in wheat straw biomass-powered microbial fuel cells. Appl. Environ. Microbiol., 75, 3389-3395, doi: 10.1128/AEM.02240-08 
[56] Hassan, S.H., Abd el Nasser, A.Z., Kassim, R.M. (2019). Electricity generation from sugarcane molasses using microbial fuel cell technologies. Energy, 178, 538-543, doi: 10.1016/j.energy.2019.04.087

[57] Rezaei, F., Xing, D., Wagner, R., Regan, J.M., Richard, T.L., Logan, B.E. (2009). Simultaneous cellulose degradation and electricity production by Enterobacter cloacae in a microbial fuel cell. Appl. Environ. Microbiol., 75, 36733678, doi: 10.1128/AEM.02600-08

[58] Ishii, S.I., Shimoyama, T., Hotta, Y., Watanabe, K. (2008). Characterization of a filamentous biofilm community established in a cellulose-fed microbial fuel cell. BMC Microbiol., 8, 6, doi: 10.1186/1471-2180-8-6

[59] Mohan, Y., Kumar, S.M.M., Das, D. (2008). Electricity generation using microbial fuel cells. Int. J. Hydrogen Energy, 33, 423-426, doi: 10.1016/j.ijhydene.2007.07.027

[60] Rahimnejad, M., Najafpour, G.D., Ghoreyshi, A.A., Talebnia, F., Premier, G.C., Bakeri, G., Kim, J.R., Oh, S.E. (2012). Thionine increases electricity generation from microbial fuel cell using Saccharomyces cerevisiae and exoelectrogenic mixed culture. J. Microbiol., 50, 575580, doi: 10.1007/s12275-012-2135-0

[61] Gregoire, K.P., Becker, J.G. (2012). Design and characterization of a microbial fuel cell for the conversion of a lignocellulosic crop residue to electricity. Bioresource Technol., 119, 208-215, doi: 10.1016/j.biortech.2012.05.075

[62] Rezaei, F., Richard, T.L., Logan, B.E. (2008). Enzymatic hydrolysis of cellulose coupled with electricity generation in a microbial fuel cell. Biotechnol. Bioeng., 101, 1163-1169, doi: 10.1002/bit.22015

[63] Sahu O. (2019). Sustainable and clean treatment of industrial wastewater with microbial fuel cell. Results Eng., 4, 100053, doi: 10.1016/j.rineng.2019.100053

[64] Menicucci, J., Beyenal, H., Marsili, E., Veluchamy, R.A., Demir, G., Lewandowski, Z. (2006). Procedure for determining maximum sustainable power generated by microbial fuel cells. Environ. Sci Technol., 40, 1062-1068, doi: 10.1021/es0511801
[65] Chandrasekhar, K., Amulya, K., Mohan, S.V. (2015). Solid phase bio-electrofermentation of food waste to harvest value-added products associated with waste remediation. Waste Manag., 45, 57-65, do i : 10.1016/j.wasman.2015.06.001

[66] Schröder U. (2007). Anodic electron transfer mechanisms in microbial fuel cells and their energy efficiency. Phys. Chem. Chem. Phys., 9, 2619-2629, doi: 10.1039/B703627M

[67] Raghavulu, S.V., Babu, P.S., Goud, R.K., Subhash, G.V., Srikanth, S., Mohan, S.V. (2012). Bioaugmentation of an electrochemically active strain to enhance the electron discharge of mixed culture: process evaluation through electro-kinetic analysis. RSC $A d v$., 2, 677688, doi: 10.1039/C1RA00540E

[68] Srikanth, S., Mohan, S.V., Sarma, P.N. (2010). Positive anodic poised potential regulates microbial fuel cell performance with the function of open and closed circuitry. Bioresource Technol., 101, 5337-5344, doi: 10.1016/j.biortech.2010.02.028

[69] do Nascimento, J.M., de Oliveira, J.D., Rizzo, A.C., Leite, S.G. (2019). Biosorption Cu (II) by the yeast Saccharomyces cerevisiae. Biotechnol. Rep., 21, e00315, doi: 10.1016/j.btre.2019.e00315

[70] Lin, T.C., Chen, C. (2004). Enhanced mannanase production by submerged culture of Aspergillus niger NCH-189 using defatted copra based media. Process Biochemistry, 39, 1103-1109, doi: 10.1016/S00329592(03)00218-8

[71] Nisa, S.L. (2007). The production of fungal mannanase, cellulase and xylanase using palm kernel meal as a substrate. Walailak J. Sci. Technol., 4, 67-82 